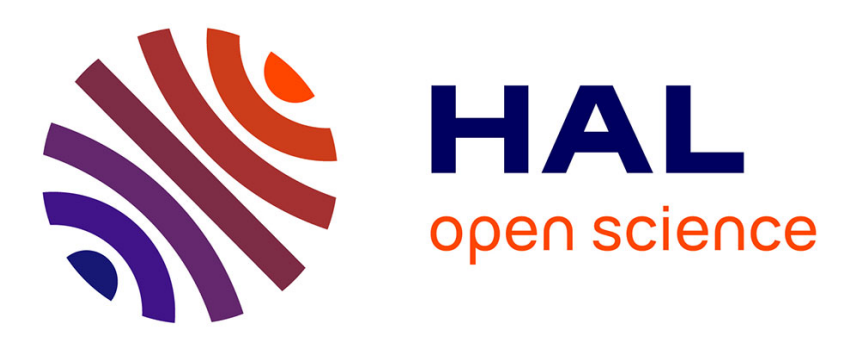

\title{
A scientific note: Survey for Nosema spp. in preserved Apis spp.
}

Brenna E. Traver, Richard D. Fell

\section{To cite this version:}

Brenna E. Traver, Richard D. Fell. A scientific note: Survey for Nosema spp. in preserved Apis spp.. Apidologie, 2015, 46 (2), pp.194-196. 10.1007/s13592-014-0306-1 . hal-01284429

\section{HAL Id: hal-01284429 \\ https://hal.science/hal-01284429}

Submitted on 7 Mar 2016

HAL is a multi-disciplinary open access archive for the deposit and dissemination of scientific research documents, whether they are published or not. The documents may come from teaching and research institutions in France or abroad, or from public or private research centers.
L'archive ouverte pluridisciplinaire HAL, est destinée au dépôt et à la diffusion de documents scientifiques de niveau recherche, publiés ou non, émanant des établissements d'enseignement et de recherche français ou étrangers, des laboratoires publics ou privés. 


\title{
A scientific note: Survey for Nosema spp. in preserved Apis spp.
}

\author{
Brenna E. Traver, Richard D. Fell \\ Department of Entomology, Virginia Tech, Blacksburg, VA 24061, USA
}

Received 17 April 2014 - Revised 8 June 2014 - Accepted 3 July 2014

\section{Nosema ceranae / Nosema apis / honey bee}

\section{INTRODUCTION}

Historically, Nosema apis was thought to be the only species to infect Apis mellifera, but recent reports showed that Nosema ceranae is a second microsporidium capable of infecting A. mellifera (Higes et al. 2006; Huang et al. 2007). While $N$. ceranae was first described in 1996 in Apis cerana (Fries et al. 1996) and initially believed to be restricted to the natural host range of A. cerana (Fries 1997), N. ceranae has been found everywhere beekeeping is practiced. $N$. ceranae has been present in the USA since 1995 (Chen et al. 2008) and the earliest published report of $A$. mellifera samples containing $N$. ceranae dates back to 1990 in samples from Uruguay (Invernizzi et al. 2009). N. ceranae has also been found in other Apis spp. such as Apis florea and Apis dorsata colonies in Northern Thailand, but no N. apis was detected (Chaimanee et al. 2010; Suwannapong et al. 2011). Samples from the Solomon Islands revealed that Apis koschevnikovi were infected with $N$. ceranae, but only in areas where A. cerana had been sympatric and no N. apis was detected (Botías et al. 2012).

$N$. ceranae has also been found in species outside of the genus Apis. Three species of bumble bee collected from 2005-2008 in South America have been found to be naturally infected with $N$. ceranae: Bombus atratus, Bombus morio, and Bombus bellicosus, but not infected with N. apis or Nosema bombi (Plischuk et al. 2009). Interestingly, in B. atratus, Nosema spores were

Corresponding author: B. E. Traver, traverb@vt.edu

Manuscript editor: Peter Rosenkranz detected in a drone and a queen, and also in queens of B. morio (Plischuk et al. 2009).

Findings of $N$. ceranae in species other than A. mellifera and A. cerana and in Bombus spp. lead to the interesting question of how widespread $N$. ceranae infections are and whether $N$. ceranae is less host specific and more capable of adapting to other species (Chaimanee et al. 2010). Previous research compared the intergenic spacer region (IGS) of $N$. ceranae isolates from A. mellifera and A. cerana and found that there were minimal differences suggesting that there is no transmission barrier between the two species (Huang et al. 2008). Initially, it was thought that $N$. ceranae jumped hosts prior to 2003, but an exact time has been difficult to determine based on limited sample numbers prior to 2003 (Klee et al. 2007). N. ceranae infections from A. cerana could cross-infect other species of honey bees as they visit similar flower species, thus facilitating fecal-oral transmission (Suwannapong et al. 2011). Export of pollen from Asia to other parts of the world could be a potential route of transmission as pollen can contain infective $N$. ceranae spores (Higes et al. 2008). It has been speculated that $N$. ceranae may have originally jumped from $A$. cerana to A. mellifera from robbing colonies as the two bee species exhibit different behavior and nectar sources (Huang et al. 2008).

Determining when $N$. ceranae expanded its host range is difficult as analysis of older samples is limited because of the lack of preserved samples. In this study, we purchased preserved, well cataloged bee samples from a reputable insect supply company. The samples had been preserved in ethanol and detailed notes were taken regarding their collection date and location. Here, we report $N$. ceranae infections in samples dating from the 1960s in multiple Apis spp. 


\section{MATERIALS AND METHODS}

\subsection{Honey bee samples}

Honey bee samples were purchased from BioQuip Products (Rancho Dominguez, CA, USA). These included A. mellifera white-eyed drones sampled in 1984 from Columbus, MO, USA.; A. mellifera drones sampled in 1993 from Columbus, OH, USA.; A. mellifera Africanized workers sampled in 1994 from Brownsville, TX, USA.; A. mellifera workers sampled in 1975 from Los Angeles County, CA, USA.; A. dorsata and A. florea sampled in 1968 from Cam Ranh Bay, Khanh Hoa Province, Vietnam. A. cerana (labeled A. indica) sampled in 1968 from Dong Ba Thin, Khanh Hoa Province, Vietnam.

\subsection{Genomic DNA extraction and real-time PCR}

DNA was extracted from individual honey bee abdomens using a Bender buffer lysis and a proteinase $\mathrm{K}$ incubation, followed by a phenol/ chloroform extraction and isopropanol precipitation as previously described (Traver and Fell 2011). Following the first centrifugation in the phenol/chloroform DNA extraction, the organic phase was solubilized with $95 \%$ ethanol so that a spore count could be performed for each bee (Mulholland et al. 2012). This modification was performed so that the genomic data for each bee could be compared to the spore count data of the same individual. qPCR was performed on individual honey bee abdomens as previously described (Traver and Fell 2011). For A. florea samples, DNA was extracted using a QIAGEN DNeasy kit (Valencia, CA) because of the small tissue size.

\subsection{Spore counting}

The number of spores contained in a sample of each lysate was determined through counts on a Bright-line hemocytometer (Hausser Scientific, Horsham, PA) as previously described (Cantwell 1970).

\subsection{Statistics}

A Wilcoxon signed rank test in JMP 11 (Cary, NC) was used to determine significant differences $(\alpha=0.05)$ in $N$. ceranae and $N$. apis levels between bees of the same species.

\section{RESULTS}

Apis mellifera workers from 1975 were co-infected with both $N$. apis and $N$. ceranae (Table I). The percent infected for both species was high: $80 \%$ for $N$. ceranae and $73 \%$ for $N$. apis (Table I), but $N$. apis levels were significantly higher than $N$. ceranae $(S=147.5, N=30$, $P<0.01$; Table I). Of the 30 bees examined, $70 \%$ were co-infected with $N$. ceranae average copy number of $2 \times 10^{4} \pm 5 \times 10^{3}$ and $5.62 \times 0^{6} \pm 1.37 \times 10^{6}$ for $N$. apis, and $10 \%$ only had $N$. ceranae infections with an average copy number of $358 \pm 109$, while $20 \%$ were not infected

Table I. Nosema spp. infection level and percent infected for various Apis spp.

\begin{tabular}{|c|c|c|c|c|c|c|}
\hline \multirow[t]{2}{*}{ Bee species } & \multirow[t]{2}{*}{ Year $^{\mathrm{a}}$} & \multirow[t]{2}{*}{ Number $^{\mathrm{b}}$} & \multicolumn{2}{|c|}{ Nosema ceranae } & \multicolumn{2}{|l|}{ Nosema apis } \\
\hline & & & $\begin{array}{l}\text { Avg. copy } \\
\text { no. }\end{array}$ & $\%$ Infected & Avg. copy no. & $\%$ Infected \\
\hline A. mellifera-white-eyed drone & 1984 & 10 & $17.7 \pm 17.7$ & 10 & 0.0 & 0 \\
\hline A. mellifera-drone & 1983 & 10 & 0.0 & 0 & 0.0 & 0 \\
\hline A. mellifera-Africanized & 1994 & 30 & 7. $0 \pm 4.9$ & 13.3 & 0.0 & 0 \\
\hline A. mellifera & 1975 & 30 & $\begin{array}{c}1.43 \times 10^{4} \pm \\
3.9 \times 10^{3}\end{array}$ & 80 & $\begin{array}{r}3.93 \times 10^{6} \pm \\
1.07 \times 10^{6}\end{array}$ & 73.3 \\
\hline A. dorsata & 1968 & 15 & $65.7 \pm 56.9$ & 13.3 & 0.0 & 0 \\
\hline A. florea & 1968 & 15 & 0.0 & 0 & 0.0 & 0 \\
\hline A. cerana & 1968 & 15 & $58.2 \pm 14.4$ & 60 & 0.0 & 0 \\
\hline
\end{tabular}

\footnotetext{
a Year bees were sampled

${ }^{\mathrm{b}}$ Number of individual bees examined
} 
with either species. Africanized A. mellifera from 1994 had very low levels of $N$. ceranae and a relatively low incidence, and no $N$. apis was detected. A. mellifera white-eyed drones from 1984 were found infected with $N$. ceranae, but normal drones from the prior year were not infected with either species. A. dorsata and $A$. cerana were both infected with $N$. ceranae with 13 and $60 \%$ (Table I), respectively. A. cerana samples had significantly higher levels of $N$. ceranae compared to $N$. apis $(S=-27.5, N=15, P<0.01)$. A. florea was not positive for either species. Spores were only found in A. mellifera samples. The counts were $12,500 \pm 7,683$; $833 \pm 833$; and $485,000 \pm 165,144$ for white-eyed drones, Africanized workers, and workers, respectively.

\section{DISCUSSION/CONCLUSIONS}

Tracking when N. ceranae switched hosts and entered the USA is important to understand host range expansion. Here, we report the earliest known infections of Apis spp. with $N$. ceranae. $N$. ceranae was present in A. cerana and A. dorsata species dating back to 1968 , while no $N$. apis was detected. In the USA, drones from 1984 and workers from 1975 were found infected.

\section{ACKNOWLEDGMENTS}

We thank Grace Mulholland and Sean Smith for technical assistance. Funding for BET was provided by the Agriculture and Food Research Initiative Competitive Grant no. 2012-67012-19924 from the US Department of Agriculture National Institute of Food and Agriculture.

Note scientifique sur une recherche de Nosema spp. dans des échantillons d'Apis spp., conservés en collection

\section{Eine wissenschaftliche Notiz : Zum Vorkommen von Nosema spp. in konservierten Apis spp.}

\section{REFERENCES}

Botías, C., Anderson, D.L., Meana, A., Garrido-Bailón, E., MartínHernández, R., Higes, M. (2012) Further evidence of an oriental origin for Nosema ceranae (Microsporidia: Nosematidae). J Invertebr Pathol 110(1), 108-113
Cantwell, G.E. (1970) Standard methods for counting Nosema spores. Am Bee J 110(6), 22-223

Chaimanee, V., Warrit, N., Chantawannakul, P. (2010) Infections of Nosema ceranae in four different honeybee species. J Invertebr Pathol 105(2), 207-210

Chen, Y., Evans, J.D., Smith, I.B., Pettis, J.S. (2008) Nosema ceranae is a long-present and wide-spread microsporidian infection of the European honey bee (Apis mellifera) in the United States. J Invertebr Pathol 97(2), 186-188

Fries, I. (1997) Protozoa. In: Morse, R.A., Flottum, K. (eds.) Honey Bee Pests, Predators, \& Diseases, pp. 59-76. A.I. Root Company, Medina, $\mathrm{OH}$

Fries, I., Feng, F., da Silva, A., Slemenda, S.B., Pieniazek, N.J. (1996) Nosema ceranae n. sp. (Microspora, Nosematidae), morphological and molecular characterization of a microsporidian parasite of the Asian honey bee Apis cerana (Hymenoptera, Apidae). Eur J Protistol 32, 356-365

Higes, M., Martín-Hernández, R., Garrido-Bailón, E., GarcíaPalencia, P., Meana, A. (2008) Detection of infective Nosema ceranae (Microsporidia) spores in corbicular pollen of forager honeybees. J Invertebr Pathol 97(1), 76-78

Higes, M., Martín, R., Meana, A. (2006) Nosema ceranae, a new microsporidian parasite in honeybees in Europe. J Invertebr Pathol 92(2), 93-95

Huang, W.-F., Bocquet, M., Lee, K.-C., Sung, I.H., Jiang, J.-H., Chen, Y.W., Wang, C.H. (2008) The comparison of rDNA spacer regions of Nosema ceranae isolates from different hosts and locations. J Invertebr Pathol 97(1), 9-13

Huang, W.-F., Jiang, J.-H., Chen, Y.-W., Wang, C.-H. (2007) A Nosema ceranae isolate from the honeybee Apis mellifera. Apidologie 38(1), 30-37

Invernizzi, C., Abud, C., Tomasco, I.H., Harriet, J., Ramallo, G., Campa, J., Katz, H., Gardiol, G., Mendoza, Y. (2009) Presence of Nosema ceranae in honeybees (Apis mellifera) in Uruguay. J Invertebr Pathol 101(2), 150-153

Klee, J., Besana, A.M., Genersch, E., Gisder, S., Nanetti, A., Tam, D.Q., Chinh, T.X., Puerta, F., Ruz, J.M., Kryger, P., et al. (2007) Widespread dispersal of the microsporidian Nosema ceranae, an emergent pathogen of the western honey bee, Apis mellifera. J Invertebr Pathol 96(1), 1-10

Mulholland, G., Traver, B., Johnson, N., Fell, R. (2012) Individual variability of Nosema ceranae infections in Apis mellifera colonies. Insects 3(4), 1143-1155

Plischuk, S., Martín-Hernández, R., Prieto, L., Lucía, M., Botías, C., Meana, A., Abrahamovich, A.H., Lange, C., Higes, M. (2009) South American native bumblebees (Hymenoptera: Apidae) infected by Nosema ceranae (Microsporidia), an emerging pathogen of honeybees (Apis mellifera). Environ Microbiol Reports 1(2), 131-135

Suwannapong, G., Yemor, T., Boonpakdee, C., Benbow, M.E. (2011) Nosema ceranae, a new parasite in Thai honeybees. J Invertebr Pathol 106(2), 236-241

Traver, B.E., Fell, R.D. (2011) Prevalence and infection intensity of Nosema in honey bee (Apis mellifera L.) colonies in Virginia. J. Invertebr. Pathol 107(1), 43-49 